\title{
A COMPARATIVE DISCUSSION OF INDIGENOUS RIGHTS UNDER CONSTITUTIONAL LAW
}

\author{
Aitor Esteban \\ University of Deusto
}

\begin{abstract}
Summary: From terra nullius to Native Title. Scheduled tribes. Reserved participation. Final agreements. Legislation without consent. Rights only exist on paper. Corporations or nations? Cultural issues. Indigenous peoples versus ethnic minorities. The end of marginalisation?
\end{abstract}

If there is one usual feature of indigenous groups it is that they are not very visible, but for a few exceptions, in the societies of their respective countries, so that for the public in general they apparently have a little influence on political, economic or social dynamics. If we ask any typical citizens how many there are, they would doubtlessly tell us that they are only a few and their numbers are getting smaller. However, if we study the world map, we will realise that there are indigenous peoples in many countries and, that rather than decreasing, their population today, in absolute figures, is more numerous than one hundred years ago. Today there are an estimated 370 million indigenous people in more than 70 countries worldwide.

Obviously, the circumstances and situations of each indigenous group or nation around the world are very different, so it would be impossible to generalise about their status. To this effect, perhaps the concept that best defines them is the word «diversity». However, within this diversity, it is evident is that during the last 12 years we have been experiencing, together with an increase in their awareness and self-esteem as nations, the recognition of their rights as collectivities in the legal systems of many countries.

At the 1993 World Conference on Human Rights in Vienna, indigenous delegates displayed banners with a letter $« \mathrm{~S}$ », fed up of official terminology referring to them as «populations», «groups» or «people» in the singular for fear of demands of the right of selfdetermination as interpreted under international law. Not «people» but «peoples», they pointed out, demonstrating their determination to be considered like any other nation. Again, the Permanent Forum created in 2000 was named «on indigenous issues» avoiding finally the word 
«peoples» ${ }^{1}$. Anyway, the creation of the Forum and other positive steps like ILO 169 show some progress has been made at international level.

And how has the legislation of different countries approached the existence of indigenous peoples within their territory? The first great difference we could point out is that whereas some countries have for centuries treated these peoples as different nations and signed treaties with them, which in many cases means that they still maintain a government-to-government relationship, others have hardly ever considered any other possibility except assimilation. This first kind of relationship is usually associated with countries of an Anglo-Saxon tradition although this is not always so, as the case of Australia shows.

\section{From terra nullius to Native Title}

Australian legal doctrine maintained that its territory was terra nullius when the first Europeans reached its shores. The idea was that no rights could belong to the Aborigines and Torres Strait Islanders because they simply roamed around the territory in small numbers. This theory maintained until the verdict of the famous Mabo case in 1992, when it was recognised that the emergence of the sovereignty of Australia or of a state like Queensland did not automatically mean the disappearance of preexisting rights, by which the aborigines could have had and could have kept valid rights to their traditional territory. This right, in the Court's opinion, was under condition that it had never been validly extinguished or, to put it another way, expressly suppressed through legislation, as long as this was not contrary to federal legislation and the Constitution. To this effect, the Racial Discrimination Act of 1975 became an unsuspected ally of this doctrine by pointing out the prohibition of the law limiting the property rights of a member of any ethnic group.

In one way or another, the Mabo precedent obliged the Australian government to promote a legislative process to adapt to the verdict. The result of this was the passing of the Native Title Act in 1993 and the setting up of the National Title Tribunal in 1994.

The limits of the Native Title concept are still being defined through the jurisprudence of the courts. Today Native Title is a communal and never individual right, which is compatible with the existence of third-

${ }^{1}$ In spite of it, in the new website of the Forum the webmaster somehow managed to achieve their goal. In the upper side of the page you can read «we the Peoples», like in the Preamble of the chater of the UN. 
party interests in the same land. Therefore, it covers a wide range of rights concerning hunting and gathering, etc. together with others such as ownership. The ruling in the Wik case established the compatibility of Native Title with the use of the land for pasture by others. But the Miriuwung-Gajerrong case, made it incompatible with the existence of a natural park, pointing out that «vesting of land in trustees for public purposes (like the national parks authority) extinguished native title». Recently (September 2002) the Martu case proved an important step by recognising to this aboriginal nation a native territory of 136,000 square kilometres, although already existing oil rights must be respected. Later however, in December 2002, the resolution of the Yorta-Yorta case has meant that the future content of the Native Title concept is doubtful. In fact, «an essential element of title claims has been proof that the claimants have maintained connections with their land and carried out traditional practices on it since the European arrival», but according to many analysts and indigenous leaders the standard of proof had now been set so high that it could be impossible for future cases to meet it. It is also very true that the frightened Australian government pushed through a legislative change in the Native Title Act in 1996 «aiming to create legal certainty for governments and third parties at the expense of indigenous title». Thus, among other modifications, the States and Territories were authorised to implement the so-called "confirmation" legislation; ATSIC estimates that native title has been extinguished without judicial authority over approximately 6 per cent of Australia since the scheme for the validation of past acts was implemented (generally titles granted between 1975 and 1993).

Nevertheless, we are speaking about a legislative and judicial process of barely 10 years. I personally believe that in spite of the judicial and legislative fluctuations, the progress, although limited, has been comparatively important. We have to admit that something is happening in a country where aborigines were not included until 1967 when the electoral census was drawn up and where children were still being «stolen» until well into the 1960s, separating them from their parents by force and offering them up for adoption by non-indigenous families hundreds of miles from their place of origin ${ }^{2}$.

2 In 1995 under preessure from the media and groups representing the Aboriginal Peoples. The Australian government convened and investigative commission to examine claims that as many as 100.000 aboriginal children were forcibly removed from their homes and transferred to the custody of white families between 1870 and 1970. after two years sifting evidence, it was concluded that over a century Australia's government had knowingly pursued a policy of genocide with respect to the Aboginal Peoples. 
On the other hand, the creation of the Aboriginal and Torres Strait Islander Commission (ATSIC), which since 1990 has been Australia's principal democratically elected Indigenous organisation, has meant the existence of an organised and legally recognised structure that directly represents all aborigines and Torres Strait Islanders, so that it helps coordinating an Indigenous response to governments on native title and land rights legislation. Every three years Aboriginal and Torres Strait Islander people elect local representatives to a network of 35 Regional Councils around Australia.

At the same time, in some Asian countries where there had been no specific legislation until now either, new provisions have emerged unexpectedly, such as the Indigenous Peoples Rights Act of the Philippines (IPRA) in $1997^{3}$, which affects $15 \%$ of the population. Although "the rights of indigenous cultural communities to their ancestral lands", were specifically acknowledged in the 1986, postMarcos constitution, nothing had been done to develop this point until IPRA was passed. In spite of its limitations, the text alarmed the most conservative groups in the country so much that they appealed to the Supreme Court, which in December 2000 rejected their claim when there was a tie among its members at 7 votes each. This Act created the National Commission on Indigenous Peoples, which is directly answerable to the President of the Republic and is composed of 7 representatives proposed by indigenous peoples from different regions of the country. Its main task is to grant the «Certificate of Ancestral Domain Title». Its decisions on this point can be taken before an Appeals Court. The Domain title can include «all areas generally belonging to ICCs/IPs comprising lands, inland waters, coastal areas, and natural resources therein, held under a claim of ownership, occupied or possessed by ICCs/IPs, themselves or through their ancestors, communally or individually since time immemorial. It shall include ancestral land, forests, pasture, residential, agricultural, and other lands individually owned whether alienable and disposable or otherwise, hunting grounds, burial grounds, worship areas, bodies of water, mineral and other natural resources, and lands which may no longer be exclusively occupied by ICCs/IPs but from which their traditionally had access to for their subsistence and traditional activities».

Apart from this right of ownership, the IPRA also recognises the following rights: Right to Develop Lands and Natural Resources, to negotiate the terms and conditions for the exploration of natural

3 Republic Act no. 8371. 
resources, right to determine and decide priorities for development, right to stay in the territories, right in case of displacement as a result of natural catastrophes, right to regulate entry of migrants, right to safe and clean air and water, and right to self-governance. The ICCs/IPs also have the right to use their own commonly accepted justice systems, conflict resolution institutions, peace building processes or mechanisms and other customary laws and practices within their respective communities and as may be compatible with the national legal system and with internationally recognized human rights.

Vested interests, including mining corporations, have sought to cripple the IPRA. Despite its flaws, the IPRA is actually a powerful legal tool for indigenous peoples: By 1997, 117 CADCs (Certificates of Ancestral Domain title) had been issued, covering some 2.5 million hectares.

\section{Scheduled tribes}

The novelty of these ordinances does not mean that we do not find old constitutional provisions to protect indigenous peoples. This is the case in India, where in principle they were intended as provisional, more specifically for 50 years, but whole validity was then prolonged in 1999, which is not surprising if we pay attention to the international situation. The constitution contemplates the protection of the Adivasis or peoples who inhabited India even before the Arian invasions and tribal peoples of Assam and neighbouring states in Northeast India. For fear of the obligations of international rights, they are not recognised as indigenous but are called «Scheduled Tribes». The constitution differentiates between two levels of protection, and thus the Fifth Schedule creates Tribal Advisory Councils, which are used to help state governors to apply laws in indigenous areas. Unfortunately, this clause does not acknowledge communal rights to land, nor to mineral resources, nor to their consuetudinary institutions. The Sixth Schedule, however, which is applied to the tribes in the north-east, creates autonomous districts and regional councils that draw up laws concerning agricultural, livestock and residential uses of the land (although not forestry) and their traditional institutions are acknowledged in such a way that they can administer their own resources. On the other hand, the constitution recognises the right to affirmative action, among other rights, for all the scheduled tribes, reserving seats for them in the parliaments of the states and of the Union, and a quota of jobs for civil servants in the public administration and in education. 


\section{Reserved participation}

New Zealand is another important case study. A fundamental document in regulating Maori and Pakeha relations is the Treaty of Waitangi, signed by most Maori tribes with the British Crown in 1840. In Aotearoa/New Zealand the Waitangi Tribunal (created in 1975 but unnoticed until 1983) investigates claims of infringements of Maori rights under this Treaty. The tribunal has earned a reputation for sound judgement and reasoned argument not only accepting a jurisprudence shaped by western custom, but interpreting concepts of justice, fairness and ownership from Maori perspectives. But it only can make recommendations and not all of them are implemented. In 1994 the government released details of its proposals for the settlement of Treaty of Waitangi claims. It was intended to provide durable, full and final settlements on an Iwi by Iwi basis. It should be mentioned that identification for Maoris is stronger with their Iwi or tribe than as a national collective. In this process, for instance, the law that gave autonomy to the Ngai Tahu tribe, the fourth in size according to number of members, was approved, making it the first Iwi to be granted legal status as such. Maori land is important for economic development but more than that, remains a cornerstone for Maori identity and a sense of continuity with the past. The Te Ture Whenua Maori Act or Maori land Act was approved in 1993. This Act, based on the Treaty of Waitangi, recognized Maori lands as an asset inherited from earlier generations, with its main purpose being to make sure that the owners of Maori land keep it so it is passed on to future generations.

An important feature of Maori representation is that there are reserved seats for Maori in Parliament. The New Zealand Parliament is unicameral and has 120 seats, seven of which currently are reserved for Maori elected on a separate Maori roll. However, Maori also may run for, and have been elected to, non-reserved seats. The number of Maori electorate seats can rise or fall depending on the number of Maori who choose to be registered on the Maori electoral roll. A change in the number of Maori seats can affect the number of General seats in the North Island. As a result, the process of re-drawing electorate boundaries cannot begin until the Maori Electoral Option has been held, every 5 years. Since 1993 the number of Maori seats has increased from 4 to 7 , as more Maori have made this choice. If all Maori were enrolled on the Maori roll there would be 13 seats. The origin of these Maori seats is old: Four separate Maori electorates were established in 1867 as a temporary measure but for only five years. They stayed for 129 years, 
and since 1993, Maori voters themselves have decided how many Maori electorates there will be.

This reserved participation also appears in the new Colombian constitution of 1998, establishing 5 seats in the lower house and 2 senators ${ }^{4}$ elected in the indigenous constituency. Another case where direct indigenous representation exists in a parliament is in Taiwan, where 8 seats out of 168 are reserved for fifty-seven aboriginal tribes.

\section{Final agreements}

But in countries with a tradition of signing treaties, there were peoples with whom it was not considered necessary to sign any kind of agreement, either because of their unwarlike nature, their geographical marginalisation or other reasons. This is the case of Northern Canada, of British Columbia and of the Totono O'odham in Arizona. The Canadian government has recently promoted the carrying out of Final Agreements. Two have been signed until now: The Nisga' a case in 1998 and the recent Tlicho agreement ${ }^{5}$ standing out. This would involve reaching an out of court agreement in exchange for renouncing any other future right that might correspond to them. But is it possible for one generation to renounce the historic rights that a people have had for many generations? I believe that the question legally offers extensive scope for discussion and in no case a univocal answer. Many legal experts agree that the right of a people to their self-government and the right to decide their future can not in any way expire, because it would be an intrinsic part of the substantial content of their rights. In other words: Their right to self-determination cannot be extinguished in one single act. In Europe, any of the minorities who claim a greater degree of self-government and even their own space in Europe (the Basques, Catalans, Scots or Flemish, for instance) would consider the very idea unacceptable. As established in the final clause of the Basque Accord on Autonomy by signing an Agreement you are not renouncing to the rest of your rights, which could be claimed in the future. But I also understand that it is very easy to do this in a situation where one

4 Art. 171 Colombian Constitution (1998).

5 Signed finally on August 25th 2003. It gives the 4.000 Tlicho (also known as Dogrib) ownership of an area as big as Switzerland together with its natural resources. They will also get 152 canadian dollars in cash and their local goverments will be able to make and enforce laws, collect taxes, levy royalties on mines and regulate land use, education, family law and traditional medicine. 
enjoys autonomy and has one's existence as a people minimally ensured culturally. To this effect, I believe the creation of Nunavut as a Canadian territory in 1999 to be encouraging and satisfactory. Instead of setting aside a reserve Inuit ${ }^{6}$ it was decided to turn that area into a «Territory», a legal status only below that of a «Province», although very similar to it. The choice was difficult because voting for the land claim agreement meant they would have to exchange aboriginal rights and title to all land and water in the Nunavut Settlement Area, save for the 355,842 square kilometres of Inuit-owned land. 84.7 per cent of voters endorsed the agreement. It was the largest claims settlement in Canada in terms of financial compensation and land: $\$ 1.1$ billion to be paid out between 1993 and 2007, and 1.9 million square kilometres of land and water, including mineral rights to 35,257 square kilometres within the Inuit-owned land portion.

Canada Section 35 (1) of the Constitution Act 1982 provides: «The existing Aboriginal and treaty rights of the Aboriginal peoples of Canada are hereby recognized and affirmed». Constitutional recognition has meant that Aboriginal and treaty rights can only be altered or terminated by consent or by constitutional amendment. Laws contravening s 35(1) can be set aside under s 52(1) of the Constitution Act 1982. In 1990 in Sparrow v The Queen, the Supreme Court held that s. 35 constitutionalises at least part of the rights traditionally associated with the common law of Aboriginal title, including practices that form an integral part of an Aboriginal community's distinctive culture (in that case, sea fisheries) The 1992 Charlottetown Accord would have entrenched in the Canadian Constitution recognition of the «inherent right of self-government.» The Accord was rejected when put to a referendum in October 1992. But The Delgamuukw Case in 1997, following among others the Mabo case confirmed that aboriginal title does exist in Canada, that it's a right to the land itself — not just the right to hunt, fish or gather. And Aboriginal title is part of Aboriginal Rights, which, in contrast with the Australian case, are constitutionally protected. The decision was an encouraging turning point for treaty negotiations.

Section 25 creates an exemption to the Canadian Charter of Rights and Freedoms, to ensure that the prohibition of racial discrimination in s. 15 of the Charter is not interpreted as abrogating Aboriginal or treaty rights. It provides a shield against diminishing Aboriginal and treaty rights in situations where non-indigenous people challenge the

${ }^{6}$ Inuit or Eskimo. This was possible as most inhabitants of that area are only Inuit. 
special status and rights of Indigenous people as contrary to equality guarantees.

\section{Legislation without consent}

Canada is now facing a controversy about the First Nation Governance Act promoted by the Government, which has passed its first reading in Parliament. The Act says it seeks greater accountability of governments of first nations, imposing a series of minimums in electoral practices and maintains, and in some cases increases, the Minister of Indian Affairs' control and authority over First Nations, such as election appeals or financial affairs. These points coincide to a great extent with the caustic remarks made in recent years from position not in favour of aboriginal autonomy. All parties agree that the Indian Act is a major obstacle to change. Yet if this Bill is passed the Indian Act will not be derogated in many of its articles. The truth is that the project is meeting the opposition of the First Nations Assembly. Even groups like the Kairos ecumenical initiative, which is a coalition of Canadian churches, church based agencies and religious organizations dedicated to promoting human rights, and which includes for instance the conference of catholic bishops of Canada, has shown its disagreement. In my opinion, it doesn't seem that any initiative which does not enjoy a minimum consensus among those affected can be successful.

That is precisely what has happened with the Indigenous Act in México. Until 1989 México maintained an assimilationist policy through the Indigenous National Institute. It was then that it included, for the first time, in article 4 of its constitution, that the «Mexican nation has a pluri-cultural composition sustained originally on its indigenous peoples». It continues by stating that the law would protect the development of their languages, cultures, uses and customs and specific forms of social organisation. Nevertheless, no legislative development was carried out. On 1 January 1994, the Zapatista uprising in Chiapas took place. As a consequence, Congress passes a law: «Ley para el diálogo y la reconcialición en Chiapas» on 9th March 1995, which states as following:

- The Government and EZLN will negotiate an Agreement for Concordance and Pacification. Once the Agreement is signed, a Committee will be created to oversee its accomplishment.

- Guarantee the refugees they can go back to their old settlements. 
- The COCOPA (Comisión de Concordia y Pacificación) is created (An ad hoc Committee of the Congress and two representatives of the Executive and Legislative bodies of Chiapas). It will coordinate with the negotiators.

After a series of confrontations, this Concord and Pacification Commission (COCOPA) was created and finally reached the San Andrés Agreements in January 1996. This important document assures these points:

-Indian Peoples should be recognized in the Federal Constitution. Autonomy will be guaranteed.

- Reorganization of administrative divides in the States, adapting them to the realities of Indigenous peoples. Autonomy model will not necessarily be the same for all Peoples in a State, their different characteristics should be acknowledged.

-Assure political representation of Indian Peoples promoting changes in electoral districts.

- Traditional Judicial systems will be recognized and validated directly by the Courts.

- Native languages will be promoted and education will be bilingual, guaranteeing literacy in the native tongue.

- Protection for Indigenous emigrants.

- Media tools (radios and so on) will be given to Indian Communities.

- Protection of sacred sites and ceremonial centers. Assure the legal use of plants and animals for ritual and religious purposes.

Based on these, COCOPA presented a bill, which was rejected by President Zedillo. The situation remained on hold until April 2001, with President Fox in office, when the parliament unilaterally approved the Act of Indigenous Rights and Culture without seeking the approval of indigenous organisations. This Act is more restrictive than the one proposed by the former Zedillo government. Especially criticised is the fact that the Indian communities are defined only as public interest bodies (entities), denying them legal status and also the right to regroup in national collectivities, and it only states that attempts will be made, although without any obligation, to adapt electoral constituencies for better indigenous representation. Moreover, it eliminates the possibility of indigenous groups being able to demarcate an autonomous territory. In spite of the evident reduction of the expectations created in 1996, it is obvious that a lot is changing. One example of this is the approval, in late 2002, of the General Act for the Language Rights of Indigenous Peoples, which recognises the right to a bilingual education and the use 
of their languages in dealings with the public administration, as well as the promotion of Indian languages.

\section{Rights only exist on paper}

Latin America is an area where legal development is just starting but where it could have a strong future. In fact, indigenous groups are the majority of the population in some regions. The Quechuas, Aymaras or the different Mayas groups, with millions of persons, are predominant majorities in extensive territories. Starting in the 1990s, indigenous rights started to be recognised in constitutions. This means certain progress, unpredictable just a few years ago. Nevertheless, the big challenge for Latin America is to transfer those rights from paper into practice. Let's briefly review them.

The oldest ongoing precedent of indigenous autonomy can be found in the case of the Kunas of Panamá, who obtained an Autonomy Act in 1953 which is still in force, although the constitution does not make any mention of this situation.

The Political Constitution of Nicaragua, passed in 1987, defined the multi-ethnic and pluricultural nature of the Atlantic Coast, with Article 8 establishing that «Nicaragua is by nature multi-ethnic and an integral part of the Central American nation». The Statute of Autonomy for the Atlantic Coast, also known as Act 28, was approved the same year and recognises the right of the indigenous peoples and ethnic communities on the Atlantic Coast to elect their own bodies of regional administration, to preserve their ancestral cultures and to decide about the use and exploitation of their land and of their natural resources. In spite of its importance, the Statute of Autonomy for the Autonomous Regions has still not been developed by the National Assembly, which greatly restricts its real application.

In this situation of autonomy that existed more on paper than in reality, the Awas Tingni community of the Mayagna nation won an important victory in its legal battle against the Nicaraguan government. On 17 September 2001, the Inter-American Court of Human Rights pronounced its verdict in which it ruled that Nicaragua was violating the international law concerning human rights, by denying the community its rights to ownership, suitable legal protection and equal protection before the law. The Court considered that the legal measures applied by Nicaragua for the protection of indigenous lands were «precarious and ineffective». It ordered the Government to demarcate the traditional lands of the Awas Tingni community and to establish 
new legal mechanisms to demarcate the traditional lands of all the indigenous communities in Nicaragua, which unfortunately it hasn't until now.

But perhaps the most advanced legislation in this role is in Colombia, although some recent changes have devaluated its importance. The indigenous population represents $2 \%$ of total inhabitants, but occupies $24 \%$ of its national territory. The constitution of 1990 recognises the right to collective property and orders the establishment of indigenous territories so that they form an organisational level in the state. Inside the Indigenous Territorial Entities (ETIs), custom is a source of right and a series of powers, such as development plans, land use, etc. are indicated. The forms of financing of the ETIs are also regulated. Indigenous jurisdiction to solve lawsuits in their territory is recognised, subordinated to what development law states.

Among the gains achieved in the Colombian constitution, I would like to emphasise one issue that affects indigenous nations in many other parts of the world. These refer to groups who live on both sides of the border and find serious difficulties to maintain their relationships. This is a fairly widespread situation, as demonstrated by the Totono O'odham of Arizona, who recently claimed the possibility of American nationality being given to their relatives across the border. Article 96.2 in the Colombian constitution establishes that «The members of indigenous peoples who share border territories, by applying the principle of reciprocity in accordance with public treaties are Colombian citizens».

In Brazil the 1988 Constitution has, for the first time, an entire chapter devoted to indigenous societies. It means an important change, although its legislative development is proving somewhat slow. Thus, for example, the Statute of the Indian is a code promulgated in 1973 regulating several aspects of the interface between indigenous societies and the rest of Brazil. It has points that are not consistent with the present Constitution but after 15 years has still not been reformed. The constitution rejects the idea of "assimilation» in such a way that it specifically protects the social organisation, customs, languages, beliefs, traditions and native rights over the lands that they have traditionally occupied. The constitutional development legislation even foresees sentences of two to six months imprisonment for those who mock or ridicule indigenous symbols or ways of behaviour.

The recognition in Article 231 that indigenous lands need not be permanently occupied is worth mentioning. For the first time, the indigenous communities can take legal action in the courts in their own name. Indigenous lands must be demarcated and are inalienable and 
unavailable, and the rights to them never expire. It does not, however, recognise the right to ownership of the subsoil, whose exploitation remains in the hands of the Federal Congress instead of the government, as it had before. Indigenous lands are not yet completely regulated despite the constitutional mandate stipulating that this should be completed by 1993 . Nowadays, only $2 / 3$ of these have been duly ratified by Presidential decree, the total area of the indigenous lands being around 90 million hectares.

The Ecuadorian Constitution (1998) establishes the «right to identity» of the Indian peoples, and to the use of symbols and emblems that identify them. The peoples' authorities can pass judgment by applying consuetudinary norms and procedures (provided they are not contrary to the Constitution or to law). According to the Constitution, the «ancestral possession» of community land is inalienable, stating the right to participation in the exploitation of resources and the preservation of the traditional forms of social organisation.

Argentina $^{7}$, Perú ${ }^{8}$, Bolivia ${ }^{9}$ and also Chile represent a series of countries which, even though they include brief references in the constitution, do not specify the exact framework of rights that might be effectively claimed. The development legislation in Chile, in my opinion the most advanced by far, through Act 19253 or the Indigenous Peoples Act (1993) grants legal status to indigenous peoples only as communities or municipalities. This means that certain rights might be recognised for an Aymara or Mapuche village, but never to the Mapuche nation as such, in spite of there being geographic continuity between the villages.

\section{Corporations or nations?}

Another issue that has fascinated some european scholars is how indigenous nations can be considered mere corporations by some legislators. Of course the most evident case is the Alaska Native Claims Settlement Act of 1971 ANCSA, which established regional and village corporations. It is true that the Alaska Federation of Natives AFN enthusiastically approved the bill by a vote of 511 delegates for, and 56 against. Alaska's

7 Constitution $1994 \mathrm{sec} 75.17$. Indigenous policy and aboriginal communities support Act (1985).

8 Constitution $1993 \mathrm{sec} .89$ and sec. 149.

9 Constitution $1965 \mathrm{sec}$ 171. Popular participation act 1994. Education act 1994. 
68,000 Natives and 220 tribal governments, who gave up all but 44 million acres and were to receive $\$ 1$ billion dollars through ANCSA corporations, not reservations, were organized to administer the proceeds from the historical land claims settlement for Alaska Natives. These corporations are theoretically to protect native interests and encourage economic, social, and political integration, but their success has been hotly debated. The proposed justification for this method was that corporations, run by Native people, would protect the remaining lands for Native use and yet provide the means for their financial resources to prosper in America's corporate society The potential profits derived from these corporations would then be utilized to improve the village communities from which they originated by providing financial resources to operate their local governments. But after more than 30 years the result is that most villages remain in bad condition. Inadequate infrastructure, high unemployment, underfunded tribal governments, and social problems say the economic gap among native people is becoming greater. The causes for this are varied and difficult to analyse. I understand that national governments do not operate like corporations, which are oriented towards profits, whereas national governments pursue other aims such as the social, solidary or cultural improvement of their society. In the same way, indigenous nations or groups can not be considered or operated like mere corporations. A culture, a nation is much more than just that. Moreover, I believe that the huge legal complexities this law is causing, for example about the nature and powers of native governments after the Venetie case ${ }^{10}$ in 1998, will lead to its being reviewed eventually.

\section{Cultural issues}

The Indian legal system in the United States has become a paradigm. Based in a government to government relationship, with its successes and with its mistakes, must be recognized as the one which has become the most legally developed through time, which, linked in many cases to the particularism in the situation of the different Indian nations from the legal point of view, would require much more lines to describe than we have available. In any case, I can

\footnotetext{
${ }^{10}$ It states that: Lands held by Village Corporations or Trusts are not Indian Territory. These native governments do not have sovereign rights like other native groups in the 48 lower states.
} 
not go on without mentioning the NAGPRA ${ }^{11}$ legislation as a milestone at world levels in the field of respect for cultural, religious and human heritage. In spite of the criticism from some scientific sectors and of the excesses, at least from a European point of view, like the Kennewick Man Case ${ }^{12}$, NAGPRA has become a fundamental reference point for future legislations.

It clarifies the right of ownership of Indian, Alaska Native, and Native Hawaiian human remains and artefacts, including funerary objects, religious artefacts, and objects of cultural patrimony, found on Federal or tribal lands. It also establishes conditions for the excavation or removal of Native American human remains or cultural artefacts, including the consent of the appropriate tribe or Native American organization and establishes notification requirements for the inadvertent discovery of Native American human remains or cultural artefacts on federal or tribal lands. There are also established criminal penalties for the sale, purchase, or transport of Native American human remains or cultural artefacts without a legal right of possession. The law directs federal agencies and museums receiving federal assistance to identify the geographic and tribal origins of human or cultural artefacts in their collections, and require the return of the remains or artefacts to the appropriate tribe or Native American organization upon request.

We should also point out that however there is another factor for concern which, in my opinion, has been socially neglected in the USA: Indigenous languages. In 2002, UNESCO published its «Atlas of World's Languages in danger of disappearing». It states:

Although some reversals of negative attitudes and policies involving Indian languages were observed in the 1970s in the United States, there was a backlash of conservatism and a strengthening of the «English only» policies in the 1980s that exacerbated the situation of the ongoing extinction of Amerindian languages (Zepeda and Hill,1991), and it is still continuing unchecked.

... there are still languages which have not been documented and are in urgent need of study before they disappear completely.

11 Native American Graves Protection and Repatriation Act 1992.

It was created to protect cemeteries on federal and tribal lands, and to provide a way to return the human skeletal material and associated funerary objects in the nation's scientific and museum collections to culturally affiliated tribes.

12 The case refers to some prehistoric human remains not connected with any modern indian tribe which could give some important clues about the early presence of people in America. Several indian tribes oppose the scientific study of the remains to the frustation of many scholars. 
Each language reflects a unique world-view and culture complex, mirroring the manner in which a speech community has resolve its problems in dealing with the world, and has formulated its thinking, its system of philosophy and understanding of the world around it. With the death and disappearance of such a language, an irreplaceable unit in our knowledge and understanding of human thought and worldview is lost forever.

I believe that each and every one of the languages which are spoken in a country should be considered as part of its cultural wealth and heritage of all its inhabitants. With the disappearance of a language, we all lose, not only those who spoke it. A world that meets to discuss the need to protect biodiversity should also concern itself with cultural diversity. Some efforts have recently been made, for example the Native American Languages Act of 1992 establishing a program to support a wide range of activities aimed at ensuring the survival and continued vitality of Native American languages, although the initial programs were not implemented until 1996, or the Bilingual Education Act in 1994. But it is the social esteem which makes the difference. Even though they do not affect the scope of tribal sovereignty, the «English only» motions in California and Arizona indicate a mood not very inclined towards difference. In any case, the survival of indigenous languages does not only depend on having the right legal, economic and social prestige, but rather will finally depend on the will of the indigenous groups themselves to keep them alive.

It is precisely in the cultural field where the greatest protection is given to the rights of the Sámi of Scandinavia. In fact, the everyday use of the Sámi language is decisive in determining a person's right to be considered a Sámi under the law. Your first tongue must be Sámi or have a father, mother or grandparent who had it as first. There are now Sámi Parliaments in Finland, Norway and Sweden. Constitutional reforms in Norway have resulted in recognition of the country as bicultural —Norwegian and Sámi- A 1988 constitutional amendment (s. 110a) provides: It is the responsibility of the authorities of the State to create conditions enabling the Sámi people to preserve and develop its language, culture and way of life. Therefore Sámi are considered a separate people although they are Norwegian subjects The Sámi parliament was created in 1989. In Sweden and Finland their rights are more limited, even though both have their respective Sámi Languages Act. In both cases, the Sámi parliament is chiefly a state administrative body under government jurisdiction. Its main power is to launch initiatives on Sámi issues. The main issues they deal with are Reindeer 
Herding rights and hunting rights. What is certain is that there has not been extensive legislative development, although the existence of the respective parliaments enables the voice of the Sámi to be raised officially.

\section{Indigenous peoples versus ethnic minorities}

All this worldwide agitation and the tone of the contents of many of the claims means that it makes increasingly more sense to wonder about the difference between the concepts of «indigenous group» and «ethnic minority». In fact, it is terminology adapted to the world of international organisations. At the United Nations there are two completely differentiated Working Groups at the very heart of the SubCommission on Prevention of discrimination and Protection of Minorities. It is true that most indigenous groups agree with this because they believe it benefits them. Indeed, it is better to be a big fish in a small pound than a small fish in a big pound. Like this, they can attract international attention as leading players. Moreover, the peoples classed as «minorities» are usually perceived by the nation states as potentially dangerous for their territorial integrity, which would be harmful because the current concept of self-determination for the indigenous world is identified in most cases with self-government and not with self-determination for independence (although there are exceptions like the Nagas in India). On the other hand, propaganda becomes easier, especially among Europeans who, in general, feel attracted to the clichés around indigenous life (Pacha Mama, simple life, ecology, spirituality...). It is true that international law does not oblige anyone to define themselves as indigenous or a minority, so therefore it is logical and normal for everyone to use the classification that is most beneficial at the time. But the border between both concepts is less clear than we could think. Let's take the Basques as an example. Always considered as an ethnic minority, I'll try to demonstrate for a moment that they are also indigenous people. The Basques are a nation of 3 million people between Spain and France who, according to researchers, have lived in the same place since the Palaeolithic period, since before the invasions by Indo-European peoples. In their language, words such as «axe» or «knife» are derived from the root term meaning «stone», and there are always a considerable number of anthropologists studying them. What makes an indigenous nation? Awareness of being a group? Basques have it. Common ancestors? Without any doubt. A different language? Basque language 
is quite original: Like the Zuni language, it is an isolate, not related to any other language in the world. Having a common history and an ancestral bond with the territory? No problem. Having a tribal structure? That is not an indigenous requirement. There are peoples with tribal structures, like the Kurds or the Arabs themselves in Iraq who are not considered indigenous and there are indigenous peoples, such as the Sami or many Quechuas, who are not tribal. Made up of extended families? This is not the case of the Inuit or of the Sami or the Ainu of Japan. Perhaps having arrived before other groups to the place they inhabit and then being surrounded by them? That is the case of Basque people. Keeping alive some traditional institutions? Maybe not as many as other nations, but Basques have a good number of them. Being different in lifestyle from the majority of society? Fine, that's where you've got me trapped. OK, Basques are not a Native European People. But for the same reason, perhaps we should not consider the Pequot as an indigenous group ${ }^{13}$, to give just one example. Well, this whole exercise does not seek to find a definition but to show that the profiles of the term «indigenous» are not as clear as they seem and that the difference between indigenous nation and ethnic minority is, nowadays, more tactical and less clear at the strict level of claims. After all, ethnic minorities and indigenous peoples share the essential: The conviction that they are and the will to continue being differentiated societies, neither above nor below the rest, who can decide about their future by themselves.

\section{The end of marginalisation?}

I mentioned earlier that one of the features of indigenous groups was that up to now they have not been present among the ruling classes of their respective countries; they were marginalized societies, elusive due to their spirit of survival, unknown by the general public of their own countries. Nonetheless, we are finding recently that pride in being indigenous is appearing and this pride is taken up even to the highest levels of the very states which have always marginalized them. Since January 2001, Floro Tunubalá has been the Governor of the Colombian

13 Pequots are a small tribe of Connecticut which for decades was considered vanished. Unexpectly two families with a few far Pequot ancestors and who kept no traditional ways got federal recognition as a tribe. Nowadays they run the biggest casino in the USA. 
region of Cauca. He dresses in the traditional manner of his Guambiano people as a statement of identity and collective self-esteem. Another indigenous politician, Evo Morales, stood for the presidency of the Republic of Bolivia in 2002 and finished in second place. Ten years ago, nobody would have imagined that Nina Pacari, an indigenous Quechua who takes pride in her origins and dresses in the traditional way, was to become the Minister for Foreign Affairs of the Ecuadorian Government. Moreover, this fact is even more remarkable considering that she belongs to an indigenous political party (Pachacutic), which is the political platform for the Confederation of Indigenous Nations of Ecuador (CONAIE).

This leads us to another consideration, which is that but for a few exceptions, there were no indigenous political parties until the 1980s. During the 1950s and 1960s, it could have been said that there were no Indians in Central and South America: they were simply called peasants, without any reference to their being indigenous. Once again appears the socially-excluded, distrustful Indian, whose very existence was denied. This is the period when movements on the political left tried to mobilise these groups by identifying the national question with class struggle. History tells us that that attempt failed.

Today, after having started in the 1990s, people directly identify themselves as indigenous, and many people publicly display their pride in being Indian, something unheard of just a few years ago. The US Census is a good example of this. In twenty years Native Americans have more than triplicated their numbers.

And this leads us to considering about what happens with the identification that people of mixed ancestry make of themselves. It is more than well known that many indigenous people have traditionally denied their origin in order to escape social exclusion; if the collective self-esteem changes in the medium or long term, it is possible to think of a re-identification of extensive groups and even of people of mixed ancestry. Achieving these social identifications is a key factor that might mean that some indigenous collectivities could have future viability in the creation of new political structures with greater powers and scope. It is difficult to state precisely what kind of political structures these will be, but I understand that the political evolution of states as we know them nowadays is an irreversible fact. And in this new political reorganisation, indigenous peoples could find a place with representation at state and supra-state level. I am aware that this last statement might sound like science fiction, especially on the American continent, where the sovereignty of states remains firm and immutable. But to let our imagination fly. In 1978 Helene Carrere D'encausse, 
wrote a book entitled «L'Empire Eclaté» «Decline of an Empire», which predicted the disappearance of the then all-powerful Soviet Union, overcome by the centrifugal force of its internal nationalities. Most considered her book to be nonsense. Nobody suspected that the Iron Curtain was to come down in 1989 and that the Soviet Union would break up as it did. In my case, I am not going to predict anything similar. But having mentioned the precedent of historical surprise, I would like to express some of my projections. I believe that the dynamics of ethnic identity is an emerging force in the modern world. The world is witnessing a revival of ethnic identities throughout the length and breadth of the world. And the indigenous world is not an exception to this phenomenon. Perhaps it is not a contradiction but rather a logical consequence that in the world of Internet and of the great languages of international communication, such as English or Spanish, people are seeking refuge in their local identity. The human being is not a number; it is in our nature to be unique. We are immersed in a society where it is possible to make immediate contact, via Internet, with anywhere on earth, but at the same time we want to know where we come from, to be distinct from the rest, not to be confused with the masses, not to be converted into clones. What is closer becomes more beautiful, and turns into a refuge from the overwhelming sameness of the global society. And difference makes you interesting in the eyes of the rest. How is it possible that the indigenous world is much more visible in the global era than it was before? You only have to take a look on the Internet to realise that the bow and arrow have been replaced by the computer mouse and screen. The number of indigenous websites and their propaganda effect is immense Why should we be surprised? If there is something they had had to learn, and quickly, in the past centuries, it has been to adapt to new circumstances or perish. Perhaps they are not the only ones who have to adapt. Let's take a look on Europe, where we are witnessing the appearance of new political structures, which means that states are losing powers in favour of the common European institutions, while at the same time the ethnic minorities are demanding new forms of participation inside their countries and directly in the united Europe. In this way, new intermediate institutions are taking on some former state competences, thus bringing the public administration closer to the citizen, with their territorial scope corresponding to ethnic minorities in most countries. The state is being transformed, and it has no option but to adapt. I believe that Latin America, in the field of political structures, is going to find itself obliged, in the medium range, and in fact it already is at the economic level through Mercosur, for instance, to 
follow this policy of union between states. And these new realities, among which I emphasise the indigenous factor (in those cases such as the Maya, Quechua or Aymara, with large populations), are going to have the opportunity, in the longer term, to find new possibilities to create unsuspected structures of self-government. I don't know the exact shape they will take, nor their exact scope, but I dare to state that they will be a fact. I am not going to hide that this process will take a long time and will have its setbacks. We have to recognise, for example, that in the midst of this indigenous effervescence it was a surprise to see that the native groups in Guatemala missed the opportunity, by 50,000 votes, to approve a constitutional reform in the 1999 referendum that had arisen out of the peace agreements in 1996. This would have meant their recognition as Maya peoples for the first time and also recognised a wide range of indigenous rights.

But if today we know about Nina Pacari, or Floro Tunabalá, Geoff Clark, or Ole Magga, it is because the new indigenous generations are better prepared than ever. The future depends on them and on their university training. Not so much in a sense/meaning of resistance, but rather of knowing that if they respond to the challenge, in each of their countries, of personally committing themselves, they will be able to lead their respective peoples out of social exclusion and regain their self-esteem. My bet is that they will achieve it. 